\title{
Engaging My Gen Z Class: Teaching with Memes
}

\section{Aniela Mendez-Reguera ${ }^{1}$ (D) $\cdot$ Mildred Vanessa Lopez Cabrera ${ }^{1}$ (i)}

Accepted: 2 September 2020 / Published online: 9 September 2020

(C) International Association of Medical Science Educators 2020

\begin{abstract}
Fostering engagement in a traditional setting with Generation $\mathrm{Z}$ learners was difficult enough; to do so online, while most educators are battling with technology, poses an even harder challenge amid the pandemic. In an unconventional assignment, students were asked to create an Internet meme to explain any immunology class themes.
\end{abstract}

Keywords Generation Z · Zoomers · COVID-19 $\cdot$ Student engagement $\cdot$ Educational innovation $\cdot$ Meme

Members of Gen Z, true digital natives, have been navigating the internet and social networks, and immersed in video platforms since they were born. They have been described as pragmatic and socially active individuals. Most of their interaction has transferred from face-to-face to digital environments which have made them excel in representing complex situations in one-image or slang expression that makes online communication more efficient. Every time an element of a movie or expression goes viral, they are present. They live and understand these viral phenomena which shape their everyday lives and create an impact in their psyche.

The current pandemic has forced educators, from baby boomers to millennials, to plunge into an online model. If fostering class engagement in a traditional classroom setting with Gen $\mathrm{Z}$ learners was difficult, do so online, while battling with technology teachers sometimes are not used to, poses an even harder challenge during this pandemic. Understanding the key features of the learners' generation allows educators to define a strategy to approach them, as well as to understand and implement tools that could benefit the teaching-learning process.

In an unconventional effort to promote class engagement and assess student understanding of the content of the immunology class, an unorthodox assignment was given. This assignment was set as optional and had no impact on course grades, and consisted of students creating a meme of their authorship and uploading it to an online discussion board

Aniela Mendez-Reguera

aniela.mendez@tec.mx

1 Tecnologico de Monterrey, Escuela de Medicina y Ciencias de la Salud, Monterrey, Nuevo León, Mexico
[1]. These sarcastic images, part of the student's environment, have become widely known and part of pop culture and the extent to which they shape the students' perception is still unknown. Teachers sometimes overlook the utility they have to create an impact on education and promote students' engagement. The assignment required that the image depict or explained any of the second term themes or content: complement, phagocytosis, inflammation, antigen presentation, natural killer (NK) cells, etc.

A positive response resulted in 64 memes designed by 45 students, some of them posting more than once. Informal student feedback on the meme activity was positive: "It was an entertaining assignment. Through the weeks I was even collecting memes of my social media feed because I thought they would be useful to explain the processes we were discussing in class." One student mentioned that she valued this innovation as an extra-effort that the teacher was making on adapting the class to a full-online setting. Another student mentioned that when creating the meme, he worked hard not only on presenting the information but also on how to communicate effectively using visuals. The results were presented in the class web-conference session, and students voted for their favorite. The most voted image was the "two spiderman meme" to explain how the $\mathrm{C} 3$ convertase of two complement activation pathways are molecularly different but functionally the same. By making this meme, students showed the understanding that $\mathrm{C} 3$ molecules of different complement pathways may be different in composition, such as the classical and lectin pathway $\mathrm{C} 3$ convertase composed of $\mathrm{C} 4 \mathrm{~b}+2 \mathrm{a}$ molecules and the alternative pathway $\mathrm{C} 3$ convertase composed of $\mathrm{C} 3 \mathrm{~b}+$ $\mathrm{Bb}$ molecules, but their main function is the same. The runnerup contribution was a scene in the Harry Potter saga where professor McGonagall asks Ron, Harry, and Hermione why 
they are always getting into trouble. The student inserted over each wizard's character the name of neutrophil, macrophage, and dendritic cell, which are crucial in the initiation of immune responses. This showed that the student achieved an understanding of inflammation and the crucial cells in this process. There were also Shrek references, and the recent "coffin dance meme" to represent the last thing a virusinfected cell sees before it wa7.ss killed by an NK cell. Although there are many paths NK cells use to destroy infected cells, students identified the ultimate result of an NK cell with an infected or neoplastic cell.

Students made clever connections using these visual representations which are part of their digital environments, with what was discussed in the classroom. Although regardless of their generation, students and educators may prefer different learning modalities for example synchronous discussions, flipped classroom approaches, or journal clubs, but relating academic knowledge and digital resources becomes a strategy in the repertoire of available tools to engage with students after this pandemic.

\section{Compliance with Ethical Standards}

Conflict of Interest The authors declare that they have no conflict of interest.

Ethical Approval NA

Informed Consent NA

\section{References}

1. Scardina C. Through the lens of popular culture: why memes and teaching are well suited. Teach Libr. 2017;45(2):13-6.

Publisher's Note Springer Nature remains neutral with regard to jurisdictional claims in published maps and institutional affiliations. 